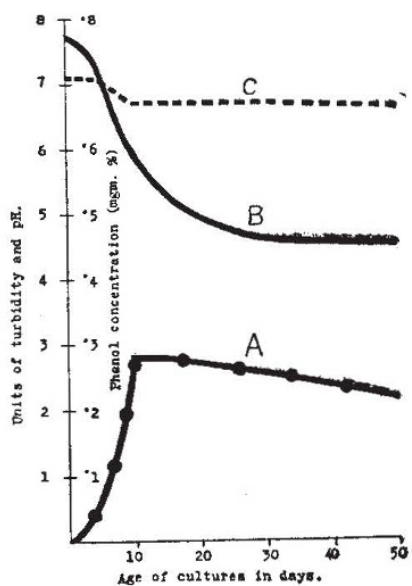

A. BACTERIAL GROWTH ESTIMATED NEPHELOMETRICALLY, EXPRESSED IN UNITS OF TURBIDITY. NEPHELOMETRIO ESTIMATIONS WERE CONTROLLED BY CELL COUNTING. $B$. PHENOL CONCENTRATION, ESTIMATED COLORIMETRICALLY ACCORDING TO FOLIN. C. $p \mathrm{H}$ OF CULTURE

tained. The rate of growth of bacteria in phenol depends on $p \mathrm{H}$ and reaches its peak at $p \mathbf{H} 7$; at this $p \mathbf{H}$ also phenol disappears most rapidly (see chart)

The strain which has been described, while growing on medium containing 0.2 per cent of glucose and 0.1 per cent of phenol, used both substrates simultaneously. The increase in the number of bacteria was greater than in the case of phenol alone, and the disappearance of phenol markedly decreased.

Achromobacter exhibits high specificity in the utilization of different aromatics as the sole source of carbon. It cannot utilize unsubstituted aromatic hydrocarbons, since it does not grow on benzene or toluene when they are used in the media as free hydrocarbons or their sulphonic acids. The hydrogenation of the benzene ring makes it available to bacterial enzymes, as was shown in the case of cyclohexane, which i a good source of carbon. The introduction into the benzene ring of chlorine, nitro, amino or sulpho groups does not make the compounds available to the bacteria investigated; but the introduction of oxygen enables the benzene ring to be split.

Nearly all the mono-, di- and tri-phenols examined up to now (for example, phenol, $o-, m$ - and $p$-cresols, catechol, resorcinol, 3,4-xylenol1-ol, orcinol, pyrogallol) are good sources of carbon for such bacteria, and the essential factor is the presence of the free phenolic group. The phenolic ethers (anisol, phenetol, diphenyl-ether) are not attacked by this strain. The esters of phenol-sulphuric, acetic, benzoic-are readily utilized as the source of carbon. Most probably the enzymatic system of the bacterial cell contains esterases which split the ester linkage, and so render the free phenol available to the bacterial cell. The introduction of oxygen makes the aromatic ring available for bacteria not only when it is present as a phenolic group, but also as an bacteria not only when it is present as a phenolic group, but also as an The mono-carboxylic acids derived from benzene (for example, benzoic, phenyl-acetic, anthranilic, "salicylic acids) produced even better phenyl-acetic, anthranilic, salieylic acids) produced even better bacterial growth than phenols. In this connexion it is curious that the two dicarboxylic acids examined, phthalic and terephthalic acids, are not attacked by these bacteria.

and benzil also were not utilized. The ability to split the aromatic ring is limited to mono-cyclic compounds; all hydroxy and carboxy derivatives of naphthalene sole source of carbon.

\section{B. SRARZYNSKI}

Departments of Bacteriology and Biochemistry,

$$
\begin{aligned}
& \text { B. SRARZYNSKI } \\
& \text { J. W. CZEKALOWSKI }
\end{aligned}
$$

University of Edinburgh,

Bacteriology Department, Royal Inflirmary, Edinburgh, and Polish School of Medicine
at the University of Edinburgh.

${ }^{1}$ Stormer, K., Z. Baltt., ii, 20, 282 (1908). Wagner, R., Z. Gerungsphys.,

4, 289 (1914). Tausson, O. W., Planta (Z. wiss. Biol.), Abt. E,

2 Fowler, G. J., Ardern, E., and Lockett, W. T., Proc. Roy. Soc., B,

83, $149(1911)$. Gray, P. H. H., and Thornton, H. G., Z. Bakt., ii,
73, 74 (1928). Grant, C. W., and Bell, C. E., Proc. Soc. Exp.
Biol, and Med., 51,266 (1942).

${ }^{3}$ Gray, P. H. H., and Thornton, H. G., Z. Bakt., ii, 73, 74 (1928).

Urease in the Gastric Mucosa and its Increase after a Meat

\section{Diet, Soya Bean Flour Diet or Urogastrone Injections}

THERE is good reason for believing that gastric hydrochloric acid is neutralized by ammonia formed most probably by urease from circulating urea. This enzyme is present in the mucosa. This mechanism was flrst noted by Luck $^{1}$ and by Luck and Seth in the dog and cat, and Linderstrom-Lang and Ohlsen noted also that in the dog the urease was most potent in the superficial rather than the deep mucosa. Furthermore, Linderstrom- for example, they held there was none present in the pig. From personal work we have shown that this ferment exists in at least man, dog, cat, rabbit, pig and rat. The amount in the frst three species of animal appears to $b$ much greater than in the latter three. Rigoni had shown its presence in man, and, like Linderstrøm-Lang and Ohlsen, had speculated on ts possible significance.

At room temperature as much as $66 \mathrm{mgm}$. ammonia nitrogen can be formed per hour from the total mucosa of a cat's stomach, this being sufficient ammonia to neutralize $47 \mathrm{ml}$. N/10 hydrochloric acid, far more acid than is formed by any cat's stomach in that time. We know that this quantity of ammonia is not released into the stomach (except, perhaps, in disease) so presumably the ammonia hydrochloric acid reaction oceurs intracellularly. There is some increase in intragastric ammonia coincidental with neutralization in both man and the cat at any rate, but not at all enough to explain the observed degree of neutralization. The urease seems to be present in largest amounts in the fundus, less in the pylorus and very litt indeed in the duodenum or small intestine proper (ef. Table 1).

TABLE 1. AMMONIA NITROgEN (MGM.) RELEASED FROM UREA PER TABLE 1. AML ONA NISOGEN (MGM.) RELEASED FROM UREA PER GRAM OB DRTY ON MOSA PER HOUR AT ROOM TEMPERATUE FROY ATAT IN SHOW NUMBER OF ANIMALS USED

\begin{tabular}{|c|c|c|c|c|c|c|}
\hline & $\begin{array}{c}\text { Sup. } \\
\text { upper } \\
\text { stomach }\end{array}$ & $\begin{array}{c}\text { Deep } \\
\text { upper } \\
\text { stomach }\end{array}$ & $\begin{array}{c}\text { Sup. } \\
\text { lower } \\
\text { stomach }\end{array}$ & $\begin{array}{c}\text { Deep } \\
\text { lower } \\
\text { stomach }\end{array}$ & $\begin{array}{c}\text { Sup. } \\
\text { duo- } \\
\text { denum }\end{array}$ & $\begin{array}{c}\text { Deep } \\
\text { duo- } \\
\text { denum }\end{array}$ \\
\hline Milk fed & $\begin{array}{r}4 \cdot 03 \\
(7)\end{array}$ & $\begin{array}{r}1 \cdot 99 \\
(8)\end{array}$ & $\begin{array}{r}4 \cdot 43 \\
(8)\end{array}$ & $\begin{array}{r}0 \cdot 47 \\
(8)\end{array}$ & $\begin{array}{r}0 \cdot 26 \\
(5)\end{array}$ & $\begin{array}{r}0 \cdot 30 \\
(5)\end{array}$ \\
Meat fed & $\begin{array}{r}16 \cdot 25 \\
(15)\end{array}$ & $\begin{array}{r}17 \cdot 31 \\
(15)\end{array}$ & $\begin{array}{r}11 \cdot 94 \\
(14)\end{array}$ & $\begin{array}{r}16 \cdot 86 \\
(14)\end{array}$ & $\begin{array}{r}0 \cdot 18 \\
(11)\end{array}$ & $\begin{array}{r}0 \cdot 31 \\
(11)\end{array}$ \\
\hline
\end{tabular}

The amount of urease which is present varies from species to species, as has been noted above; but inside the same species the concentration of mucosal urease can be increased by any one of the three following methods: by high protein diet, by soya bean flour diet or by injections of concentrated pregnancy urine. Of the first of these, experiments in cats have shown that if an animal be placed on a high protein diet, it accumulates a far higher concentration of urease at the end of as little as a week, compared with the animal placed on a milk diet (cf. Table 1). It will be noted from the table that the concentration increase is quite definite and that apparently this increase in concentration is more remarkable in the deeper part of the mucosa of the stomach, both upper and lower, than it is in the superflcial. The effect on the duodenal content of urease seems to be negligible.

TABLe 2. AMMONIA NITROGEN (MgM.) RELEASED PER GRAM PER HOUR FROM DRIED GASTRIC. MUCOSA OF RATS INCUBATED AT $37^{\circ} \mathrm{C}$. WITH UREA. ANIMALS FED PREVIOUSLY ON SOYA BEAN FLOUR OR INJECTED WITH $0 \cdot 3-0 \cdot 6$ ML. ANTUITRIN S. FIGURES IN BRACKETS SHOW NUMBER OF ANIMALS USED

\begin{tabular}{|l|c|c|c|}
\hline & $\begin{array}{c}\text { Upper } \\
\text { stomach }\end{array}$ & $\begin{array}{c}\text { Lower } \\
\text { stomach }\end{array}$ & $\begin{array}{c}\text { Duodenum plus } \\
\text { intestine }\end{array}$ \\
\hline $\begin{array}{l}\text { Soya bean fed } \\
\text { Control normal } \\
\text { fed }\end{array}$ & $2 \cdot 38(7)$ & $1 \cdot 10(6)$ & $0 \cdot 67(5)$ \\
$\begin{array}{l}\text { Antuitrin S } \\
\text { injected }\end{array}$ & $1.29(6)$ & $0 \cdot 66(5)$ & $0 \cdot 71(5)$ \\
& $1.85(5)$ & $1 \cdot 42(5)$ & $0.40(5)$ \\
\hline
\end{tabular}

The second finding, in relation to soya bean flour, was tried only on rats ; in these animals it is not practicable to divide the mucosa into superficial and deep, while mucosæ had to be analysed in groups of at least three, owing to the very small amounts obtainable (ef. Table 2). Again, there is little change in the intestinal content of the ferment. Soya bean flour was used as, though it is not active itself as a ureas enzyme, the enzyme having been destroved in preparation, it presumably contains a good remnant of the specific protein of urease which normally is present in the soya bean.

Finally, concentrated pregnancy urine was used in the form of Parke Davis Antuitrin S, in amounts varying in different experiments from $0 \cdot 3-0 \cdot 6 \mathrm{ml}$./rat/day from 10-20 days. This extract probably contains a high content of urogastrone. Again, this work has had to be done on rats, and the results are tabulated in Table 2 . A definite increase in concentration can be noted.

These three groups of experiments are interesting in so far as they show that the content of a ferment can be varied at the will of the investigator. The presence of urease in such concentrations in the investigator. The presence of urease in such concentrations in the digestion by acid pepsin. Its involvement in neutralization of hydrochloric acid is being further studied.

I wish to acknowledge with gratitude the receipt of grants from the

Medical Research Council of Ireland.

Departments of Physiology and of Biochemistry, University College, and St. Vincent's Hospital,

Duly 26.

1
2
2 357 (1925)

${ }^{3}$ Linderstrøm-Lang, K., and Ohlsen, A. S., Enzymologia, 1, 92 (1936) 4 Rigoni, M., Arch. Ital. de Biol., 84, 74 (1931). 